\title{
Working
}

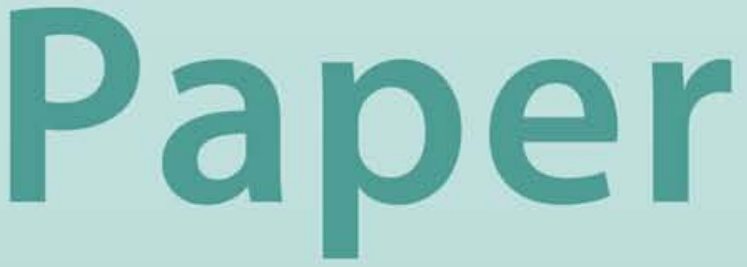


Expenditure Issues and Governance in Central America

Ana Corbacho and Hamid Davoodi 


\title{
IMF Working Paper
}

Fiscal Affairs Department

\section{Expenditure Issues and Governance in Central America}

\author{
Prepared by Ana Corbacho and Hamid Davoodi ${ }^{1}$ \\ Authorized for distribution by Sanjeev Gupta
}

November 2002

\begin{abstract}
The views expressed in this Working Paper are those of the author(s) and do not necessarily represent those of the IMF or IMF policy. Working Papers describc research in progress by the author(s) and are published to elicit comments and to further debate.
\end{abstract}

This paper analyzes Central America's track record on inequality, poverty, and quality of fiscal adjustment in relation to economic growth; health and education outcomes; adequacy of social safety nets; and governance. It then assesses the degree to which the track record can be traced to reforms in public expenditure and governance. Despite the considerable heterogeneity among the countries in the region, there are some policies that all countries need to pursue. Sustained growth and a better quality of fiscal adjustment are needed, as well as policies aimed at increasing individuals' productivity and improving governance.

JEL Classification Numbers:H5, I00, O54, O57

Keywords: Expenditure issues; fiscal adjustment; poverty; inequality; health; education; social safety nets; governance; Central America

Authors’ E-Mail Addresses: acorbacho@imf.org; hdavoodi@imf.org

${ }^{1}$ This is a revised version of a paper presented at the IMF Conference "Central America, Potential for Regional Cooperation and Integration," held in Antigua, Guatemala, July 25-26, 2002. The opinions are those of the authors and do not necessarily represent the views of the International Monetary Fund or its Executive Directors. We would like to thank Sanjeev Gupta, Robert Rennhack, and Erik Offerdal for comments; Robert Gillingham for substantial contributions to the paper; and Erwin Tiongson and Shamit Chakravarti for valuable research assistance. 


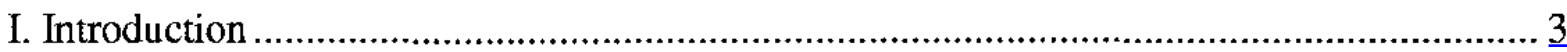

II. Economic Growth, Poverty, and Inequality ................................................................. $\underline{3}$

III. Level and Composition of Government Spending ..................................................... I

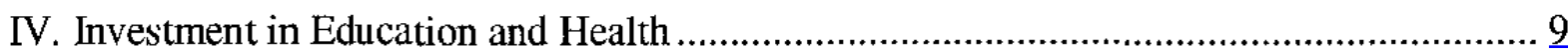

A. Provision of Education ................................................................................ 9

B. Provision of Health Services ......................................................................... 16

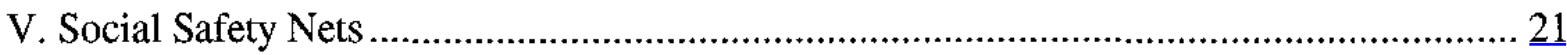

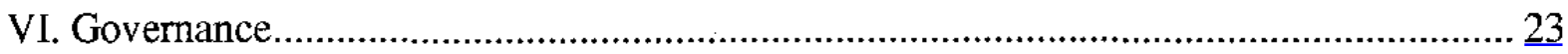

VII. Summary and Policy Conclusions …………............................................................

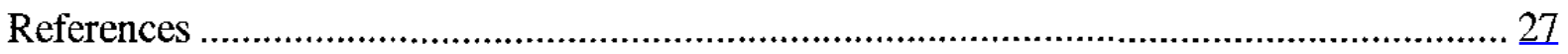

Tables

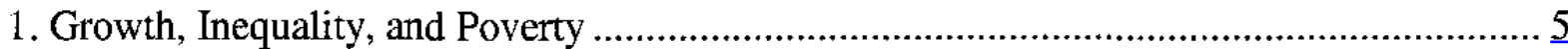

2. Economic Classification of Expenditure ………......................................................... 8

3. Returns to Education for Male Workers...................................................................... 10

4. Educational Attainment in Central America and Other Regions ..................................... 11

5. Government Education Spending......................................................................... 12

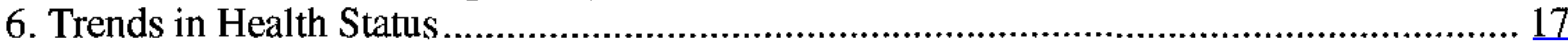

7. Government and Private Health Expenditures ............................................................. 19

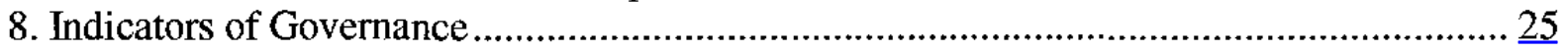

Figures

1. Relationship Between Illiteracy Rate and Spending on Education................................... 13

2. Benefit Incidence of Public Spending on Education, 1990s .......................................... 14

3. Relationship between Child Mortality Rates and Government Health Spending .............. 20

4. Benefit Incidence of Public Spending on Health, 1990s ............................................... 21 


\section{INTRODUCTION}

After a weak performance during the so-called lost decade of the $1980 \mathrm{~s}$, the economies of Central America rebounded to varying degrees in the 1990s. For the purpose of this paper, Central America consists of seven countries: El Salvador, Costa Rica, Nicaragua, Honduras, Guatemala, Panama, and the Dominican Republic. ${ }^{2}$ These countries constitute a heterogeneous group with respect to initial conditions (e.g., per capita income, presence of military conflict), exposure to external shocks (e.g., natural disasters), and pace of economic reforms (e.g., size and type of fiscal adjustments). However, these countries are facingalbeit to differing degrees-similar challenges, including high inequality and poverty, which may require common solutions.

The paper addresses three questions. First, what has been Central America's track record on fiscal adjustment, poverty and inequality, health and education outcomes, adequacy of social safety nets, and governance? Second, notwithstanding other factors at work, to what extent can the observed track record be traced to reforms in the areas of public expenditure and governance? Third, should each country in Central America follow a similar set of reforms in the area of expenditure and governance? These are indeed difficult and challenging questions that policymakers face in the new millennium, but they are not necessarily unique to Central America. The paper provides some answers by focusing on five key areas: (1) economic growth, poverty, and inequality (Section II); (2) the level and composition of government spending (Section III); (3) the level and composition of spending on educational services and health care (Section IV); (4) the design and implementation of social safety nets (Section V); and (5) recent reforms in the area of transparency and governance (Section VI). Finally, Section VII summarizes the main findings of the paper and draws some policy implications for the region. ${ }^{3}$

\section{ECONomic Growth, Poverty, AND INEQuAlity}

\section{Central American countries display diverse growth experiences and are at various stages of economic development. Growth experiences are driven by, among other things, external factors (e.g., hurricanes in Honduras and Nicaragua, or terms-of-trade shocks), resolution of armed conflict in the region (e.g., Guatemala), and the underlying economic policies and quality of institutions. ${ }^{4}$ According to the World Bank's latest calculations}

\footnotetext{
${ }^{2}$ Other definitions of the region may contain a different country composition.

${ }^{3}$ It is important to note the limitations of this paper. The paper does not provide a detailed analysis of all categories of expenditure, nor does it address all aspects of transparency and governance. A comprehensive analysis would go well beyond the scope of the paper and would entail an in-depth study of each country in the region. However, to the extent possible, the relevance of such reforms will be underscored in the discussion of the main issues of the paper.

${ }^{4}$ See Cardemil, Di Tata, and Frantischek (2000) for some details.
} 
(World Bank, 2002), Costa Rica has the highest per capita gross national income (GNI) among the seven countries, estimated at $\$ 7,980$ in 2000 purchasing power parity (PPP) terms, followed by the Dominican Republic and Panama (Table 1). Nicaragua has the lowest per capita gross national income at \$2,080 in 2000 PPP terms, just below Honduras. On a PPP basis, Costa Rica's per capita income is almost $31 \frac{1}{2}$ times Nicaragua's.

\section{The incidence of poverty in Central America is higher than in the rest of Latin} America, but both regions have poverty rates that are well below sub-Saharan Africa and the world average. This situation held throughout the $1990 \mathrm{~s} .{ }^{6}$ However, there is considerable heterogeneity among the countries in the region. Although data coverage and comparability of poverty rates vary across countries and over time, the data set compiled for this paper allows us to conclude in general that in the late 1990s Central American countries could be classified into two poverty groups: that with high poverty rates, consisting of Honduras, Nicaragua, and El Salvador; and that with low poverty rates, consisting of the remaining four countries.

The level of inequality in Central America is higher than the average in Latin America, and the level of inequality in Latin America's inequality is the highest in the world. These findings hold throughout the 1990s using different data sources and variety of inequality measures (Table 1), including the Gini coefficient and the income shares of the richest and the poorest in the population. ${ }^{7}$ The poorer countries tend to be less equal. For example, the simple correlation coefficient between per capita income in PPP U.S. dollars and the Gini coefficient of consumption in late 1990 s among the seven countries is -0.84 with a t-statistics of -4.1 . Among the seven countries, Nicaragua has the lowest per capita income and the highest poverty rate, whereas Costa Rica has the highest per capita income and the lowest inequality.

\footnotetext{
${ }^{5} \mathrm{PPP}$ exchange rates reflect international differences in the prices of goods and services. Market exchange rates measure the relative values of currencies, which are affected by more than variations in the prices of goods and services and can vary significantly from PPP exchange rates.

${ }^{6}$ Poverty is measured using the headcount index, which is the percentage of the population with a consumption or income below the poverty line. International poverty lines make it possible to compare poverty rates across countries by making adjustments for cross-country differences in prices using a common metric, the purchasing power equivalent of US\$2 per day. (Poverty rates based on US\$1 per day tell the same qualitative story, but would naturally result in lower poverty rates.) Measures of poverty for the Central American countries are based on consumption, which is judged to be a better measure of cost of living.

${ }^{7}$ There are many measures of inequality. The Gini coefficient is the most widely used measure, ranging from 0 (perfect equality) to 100 (perfect inequality). However, it has the undesirable attribute, assuming we are most interested in eliminating poverty, that the impact of the very rich has the same effect on the measure as that of the poor.
} 
Table 1. Growth, Inequality, and Poverty

\begin{tabular}{|c|c|c|c|c|c|c|c|c|c|c|c|c|c|c|c|c|c|}
\hline & \multirow{3}{*}{$\begin{array}{r}\text { Per Capila } \\
\text { Gross } \\
\text { National } \\
\text { Income } 1 / \\
2000 \\
\text { US\$ PPP } \\
\end{array}$} & & & \multirow[b]{3}{*}{$\begin{array}{r}\text { Ginwth } \\
\text { Elasticity of } \\
\text { Poverty } 3 / \\
\end{array}$} & \multirow{2}{*}{\multicolumn{2}{|c|}{ Ineguabity $4 i$}} & \multirow{2}{*}{\multicolumn{4}{|c|}{$\begin{array}{c}\text { Percentage Sharc of Incomc or } \\
\text { Consumytrion } 5 t \\
\end{array}$}} & \multicolumn{7}{|c|}{ Percent of Population Behow } \\
\hline & & & & & & & & & & & & inlemati & 1 poverty line & & & Natio & $5 t$ \\
\hline . & & \multicolumn{2}{|c|}{$\begin{array}{c}\text { Economic } \\
\text { Growth } 2 f \\
\end{array}$} & & $\begin{array}{r}\text { Gini } \\
\text { eariy } \\
1990 \mathrm{~s} \\
\end{array}$ & $\begin{array}{r}\text { Gini } \\
\text { late } \\
1990 \mathrm{~s} \\
\end{array}$ & $\begin{array}{r}\text { Survey } \\
\text { year } \\
\text { (tatest) }\end{array}$ & Gini & $\begin{array}{r}\text { Botiom } \\
20 \% \\
\end{array}$ & $\begin{array}{l}\text { Top } \\
20 \%\end{array}$ & $\begin{array}{r}\$ 2 \text { in diy } \\
\text { early } \\
1990 \text { ' } 6 t\end{array}$ & $\begin{array}{c}\$ 2 \text { al daly } \\
\text { Late. } \\
\text { I990's } 6 / \\
\end{array}$ & $\begin{array}{r}\text { Survey } \\
\text { year } \\
\text { (lalesti 5f }\end{array}$ & $\begin{array}{r}\$ 1 \text { a } \\
\text { day } 5 /\end{array}$ & $\begin{array}{r}\$ 2 a \\
\text { day } 5 t\end{array}$ & $\begin{array}{r}\text { Survey } \\
\text { year } \\
\text { (latest) }\end{array}$ & $\begin{array}{r}\text { National } \\
\text { poverty } \\
\text { line }\end{array}$ \\
\hline Costa Rica & 7,980 & -0.4 & 2.4 & -1.6 & 46.0 & 46.1 & 1997 & 45.9 & 4.5 & 51.0 & 34.2 & 30.5 & 1998 & 12.6 & 26.0 & 1992 & 22,0 \\
\hline El Saltvador & 4,410 & -2.6 & 3.0 & -1.5 & 50.5 & 55.9 & 1998 & 52.2 & 3.3 & 56.4 & 58.6 & 64.0 & 1998 & 21.0 & 44.5 & 1902 & 48.3 \\
\hline Guatemala & 3,770 & -1.9 & 1.3 & -1.2 & 59.1 & 55.8 & 1998 & 55.8 & 3.8 & 60.6 & $\ldots$ & ... & 1998 & 100 & 33.8 & 1989 & 57.9 \\
\hline Ilondaras & 2,400 & -0.8 & 0.3 & -1.4 & 54.9 & 58.5 & 1998 & 56.3 & 2.2 & 59.4 & 75.9 & 74.9 & 1998 & 24.3 & 45.1 & 12933 & 53.0 \\
\hline Panama & 5,680 & -0.5 & 3.1 & -1.3 & 56.3 & 56.5 & 1997 & 48.5 & 3.6 & 52.8 & 47.8 & 38.1 & 1998 & 14.0 & 29.0 & 1997 & 37.3 \\
\hline Jrominican Republic & 5,710 & 0.9 & 2.9 & -1.5 & 50.5 & 47.8 & 1998 & 47.4 & 5.1 & 5.3 .3 & $\ldots$ & 34.6 & 1996 & 3.2 & 16.0 & 1998 & 28.6 \\
\hline Central Anerica & 4,576 & -1.4 & 1.9 & -1.4 & 53.4 & 54.4 & as ahove & 52.3 & 3.5 & 56.7 & 57.4 & 52.4 & as ahove & 14.2 & 32.4 & as above & 42.5 \\
\hline Latin Ametica 4 / & $\ldots$ & $\ldots$ & $\ldots$ & $\ldots$ & 51.7 & 53.8 & $\ldots$ & $\ldots$ & $\ldots$ & $\ldots$ & 42.6 & 39.3 & $\ldots$ & $\ldots$ & $\ldots$ & $\ldots$ & $\cdots$ \\
\hline Latin America 5/ & 5,425 & 0.1 & 1.8 & $\ldots$ & $\ldots$ & $\ldots$ & varies & 52.5 & 3.0 & 56.6 & $\ldots$ & $\ldots$ & as aturve & 15.3 & 31.2 & varies & 32.5 \\
\hline High-ineone $O E C D$ counlies $6 f$ & 25.771 & 2.2 & 2 & $\ldots$ & $\ldots$ & $\ldots$ & varies & 30.8 & 8.0 & 39.0 & $\ldots$ & $\ldots$ & $\ldots$ & & $\ldots$ & $\ldots$ & ... \\
\hline Sub-Sabaran Africa & 1,600 & 0.2 & 0.2 & $\ldots$ & $\ldots$ & $\ldots$ & vanies & 47.4 & 4.8 & 52.9 & $\ldots$ & $\ldots$ & vanies & 42.1 & 71.9 & vatiics & 45.6 \\
\hline
\end{tabular}

Note: All regional averages use arithnietic average. Intermational poverty lines makes it possible to compare poverty actoss counnties by allnwing for cmss-country differences in prices using a common denominator, the purchasing power parity of a $\$ 1$ or $\$ 2$.

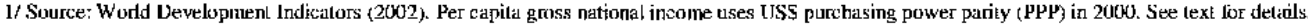

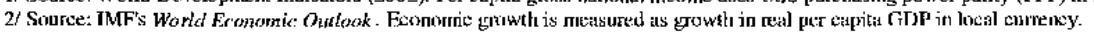

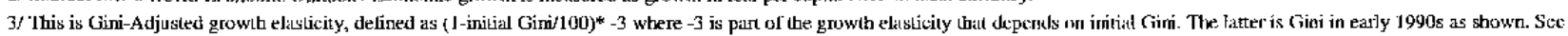
Ravallion (2001) and the rext for detsils on gtowth-adjusted clasticity.

4/ Sources: Deimingcr and Squuire (1996), Wodon and others (2000) and Szckcly (2001). Definition of poverty and inequalily lrum Szekely (2001) uses inlermational PPP for per capita consumpliun in

1985 priecs, except for masures bised on natiotzal poverty lines.

5/ Sources: World Development Indicators (20102) and World Bank Poverty assessment (2001) for the Dominican Rcpublic. Defimition of inequality measure uses per cappiti income for all

Centrat American iountries except for Nicaragua and Panana. Inequality measures have the same sample of 15 Lalin Antricun countries as snurces indicated under 3 .

6/ Source: Szckely (2001). Definition of povcrly uscs per capita consurnption in intennational PPP in 1985 prices. OF(J) countries denotes the member zountries of the Organization for tisonomic Cooperation and Developinent. 
Poverty declined on average in the 1990s while inequality increased, but substantial heterogeneity remains across countries. Of the five Central American countries for which both the poverty headcount indexes and the Gini coefficients are available in the early and the late $1990 \mathrm{~s}$, Honduras is the only country in which poverty declined while inequality rose. In El Salvador and Nicaragua, poverty rates as well as inequality rose. In Panama and Costa Rica, poverty fell while inequality remained the same.

Poverty and inequality are highly persistent over time and are highly correlated in Central America. In spite of the heterogeneity noted above, countries with high poverty and inequality at the start of the 1990 s continued to experience high poverty and inequality at the end of the decade. ${ }^{8}$ Countries with high poverty also tend to have high inequality. ${ }^{9}$ Policies that reduce poverty are likely to reduce inequality as well in the region. As the following sections show, improvement in quality of education and health for all, in general, and for the bottom end of the income distribution, in particular, are examples of such policies.

High initial inequality may be an impediment to pro-poor growth. ${ }^{10}$ Previous research (Ravallion and Chen, 1997) found that for every 1 percent increase in aggregate growth, the proportion of people living on less than USS1 day falls by as much 2.5 to 3 percent, suggesting an elasticity of poverty with respect to growth of -2.5 or -3 This result was thought to be independent of the initial distribution of income or consumption. However, some recent studies suggest that growth elasticity is not a constant; it declines with higher initial inequality (Ravallion, 1997 and 2001). Therefore, in a country with high initial inequality, high aggregate growth is needed to achieve the same reduction in poverty as in a country with low initial inequality. In other words, poverty is less responsive to growth in countries with high inequality. Reflecting the impact of initial inequality, growth elasticities in Central America vary from -1.2 (Guatemala) to -1.6 (Costa Rica). ${ }^{11}$ The experiences of Costa Rica and Honduras reveal the interaction between initial inequality and pro-poor

\footnotetext{
${ }^{8}$ For example, for Costa Rica, El Salvador, Honduras, Nicaragua, and Panama (countries with available data), the correlation coefficient between poverty at the beginning of the 1990s and the end of the 1990s is 0.96 with a t-statistic of 6.9. The correlation coefficient for the Gini coefficient between the two time periods for the same countries is 0.88 with a $t$-statistic of 3.9 .

${ }^{9}$ The correlation coefficient between poverty and inequality for the sample of seven countries is 0.74 , and statistically significant (with a $t$-statistic of 2.9 ). Persistence of inequality is also a feature of larger crosscountry data (see Li, Squire, and Zou, 1998).

${ }^{10}$ For the seven countries in the region, the correlation coefficient between growth in the 1990s and the Gini coefficient in early $1990 \mathrm{~s}$ is -0.33 with a t-ratio of -1.3 . Knowles (2001) provides a stronger correlation using a Iarger sample of countries. Recent research also suggests that it is perhaps not initial income inequality, but asset or wealth inequality that may matter more for growth, and hence, for poverty reduction (Birdsall and Londoño, 1997).

${ }^{11}$ This is the Gini-adjusted growth elasticity derived as (1- initial Gini)* -3 in which part of growth elasticity varies with initial inequality. See Ravallion (1997 and 2001) for details. Initial inequality is inequality at the start of the $1990 \mathrm{~s}$.
} 
growth. A much higher growth than a mere 0.3 percent per year is needed for Honduras to overcome its high initial inequality and achieve a higher rate of poverty reduction. For example, Honduras's growth rate in the 1990s would have had to be at least 8 percent in order to achieve the same percent reduction in poverty as Costa Rica experienced in the 1990s.

Sustained growth, among other factors, is a prerequisite for poverty reduction. Central America's growth track record has been erratic and despite the turnaround in the 1990s, growth was not high enough or sufficiently sustained in the decade to make a substantial impact on poverty. As noted earlier, the interaction among poverty, inequality, and growth is highly complex, perhaps more so for Central America than the rest of Latin America. Other factors are certainly at work, and some have been suggested earlier. Some poverty-reducing factors are structural in nature and require longer time to implement and to realize their full effects. There are also other factors that are more short-run in nature. The next sections will address both sets of factors.

\section{LEVEL AND COMPOSITION OF GOVERNMENT SPENDING}

The significant fiscal adjustment in the 1990 s was achieved largely through expenditure reductions. Central government balances in the seven countries improved from a deficit of about 6 percent of GDP in the 1980s to a deficit of about 3.5 percent of GDP in the 1990s. This adjustment was achieved through a combination of lower revenues $(0.8$ percent of GDP), and much lower expenditure (3.3 percent of GDP). Nicaragua, a country with the highest deficit in Central America, recorded the largest adjustment, reducing its deficit from 17 percent of GDP to about 11 percent, followed by Honduras and Guatemala as they emerged from the aftermath of Hurricane Mitch and armed conflict, respectively. ${ }^{12}$

Despite the sizable fiscal adjustment, by the end of the decade, central government spending on wages and salaries was large by international standards and exceeded capital investment for almost all countries. Wages and salaries in Central America exceed all major spending items; they are higher than Latin America's average, all other income groups, and even low- income countries that are eligible for HIPC relief or have reached the decision point (Table 2). These observations are valid whether wages are expressed as a fraction of total central government spending or as a fraction of GDP. El Salvador and Honduras have the highest wage bills while Guatemala has the lowest one. ${ }^{13}$

\footnotetext{
${ }^{12}$ Sources of spending and revenue are IMF's World Economic Outlook database. The magnitude of Nicaragua's deficit may be overstated as GDP is likely to be understated.

${ }^{13}$ Nicaragua's wage bill is higher than Guatemala's (as percent of GDP) perhaps reflecting the understatement of its GDP alluded to earlier. Guatemala has a lower wage bill when expressed as a fraction of total spending.
} 
On average, the current size of central government spending is low by international standards. ${ }^{14}$ Over the 1990 s, spending fell in some countries (Costa Rica, El Salvador, and Panama), rose in others (the Dominican Republic and Nicaragua) and was rather stable in two countries (Guatemala and Honduras). Part of this nonuniformity is due to drastic changes between the first and second half of the decade. Spending fell in the first half of the decade for five out of seven countries, while it increased substantially in the second half for Honduras, Nicaragua, and Guatemala, as these countries began dealing with the aftermath of hurricanes.

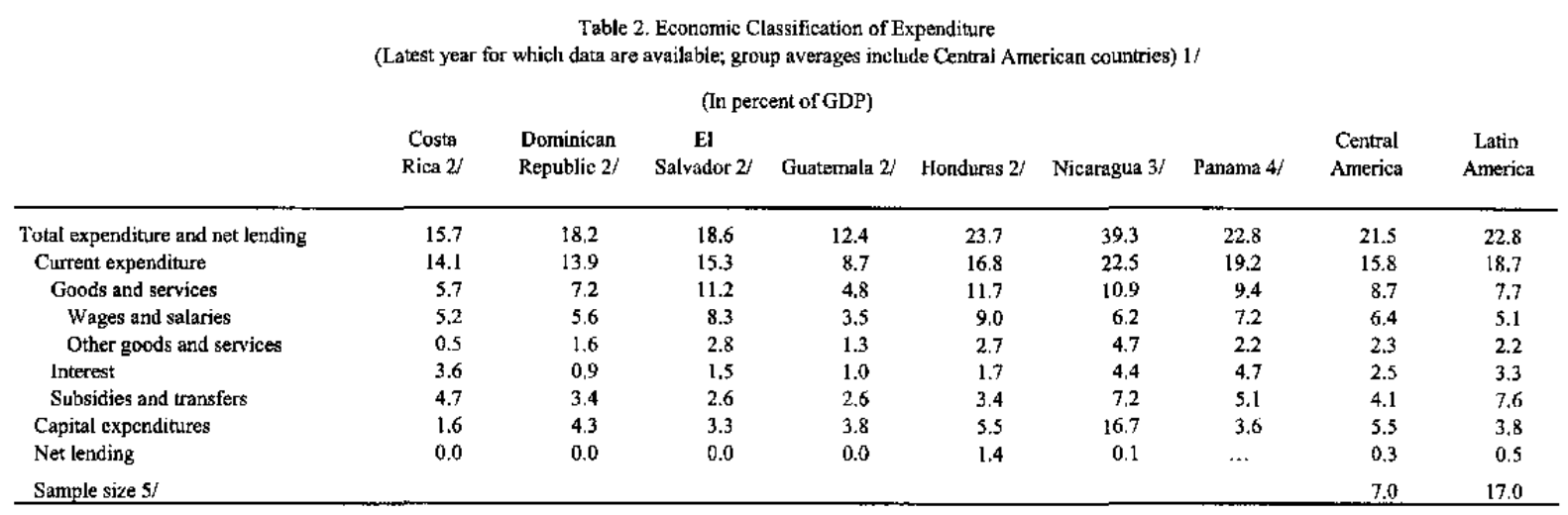

Source: GFS dalabase; national authorities; and IMF staff estimates

1/ Lalest year is mostly 1999 or 2000. For the Central Ameriean countries, latest year is 2000, except Panama for which the latcst ycar is 1999.

2/ Classified under Lower Middle Inceme group.

3/ Classified under low-income group.

4/ Classified under upper-middle-income group.

5/ Refers to the sample of sizc of countrics with data on total government spending. Sample size varies across expenditure categories. The components may therefore not add up to the total.

A growing body of literature has shown that the quality of fiscal adjustment matters, and that, for example, low government consumption is good for long-run growth. The distortionary taxation or deficit spending that tends to accompany high consumption seems to be the primary reason for the negative impact on growth (Barro and Sala-i-Martin, 1995). Some new research on low-income countries in the 1990s (Gupta, and others, 2002) has shown that a high wage bill, which is a sizable part of government consumption in many countries, reduces growth, while capital investment and spending on operations and maintenance boosts growth. Further evidence from the same study shows that initial fiscal conditions matter for growth and that the composition of spending affects the sustainability of fiscal adjustment.

\footnotetext{
${ }^{14}$ Note that these comparisons ignore cross-country differences in size of government due to differences in subnational levels of government and extrabudgetary accounts.
} 


\section{INVESTMENT IN EDUCATION AND HEALTH}

Investment in human capital is an important prerequisite for economic growth and development. Within human capital investments, education and health are considered primary factors contributing to economic performance. Investment in health and education plays an important role in countries' Poverty Reduction Strategy Papers (PRSPs). ${ }^{15}$ For instance, Honduras' PRSP has as a main objective strengthening "the human capital of poor groups by improving access to basic education and health within a framework of equity and quality that would allow them to improve their employment opportunities and income." The PRSP for Nicaragua also recognizes that investment in human capital will "enhance productivity, income and welfare."

\section{A. Provision of Education}

\section{Returns to investment in education}

From almost any perspective, education is a good investment. Several studies have found a significant positive relationship between additional years of education and earnings. For instance, returns to education in Central America are 7 percent at the primary level, 10 percent at the secondary level, and 15 percent at the tertiary level (Table 3 ). These estimates are very close to those of Latin America as a whole. The higher returns for higher levels of education can explain the large effect of education inequality on income inequality in Latin America (Inter-American Development Bank, 1998). However, it is important to remember that returns-both social and private - are difficult to measure. Moreover, the higher returns for higher levels of education are not generally found in OECD countries (Table 3). An important issue to explore is whether the findings for Latin America stand up to closer scrutiny and, if they do, whether they reflect a relatively inefficient use of resources at lower levels of education.

\section{Studies for developing countries support the notion that both quality and quantity of} education are important for earnings and academic achievement. Behrman and Birdsall (1983), using the average education of teachers as a quality proxy, estimate returns to quality and quantity of educational inputs in Brazil and conclude that the social return to educational quality even exceeds the social return to educational quantity. Case and Yogo (1999) find that reducing class size in South Africa can significantly increase returns to education for black men. They also find that schooling quality significantly affects educational attainment

\footnotetext{
${ }^{15}$ As part of the eligibility requirement under the Poverty Reduction and Growth Facility (PRGF) of the IMF, Honduras and Nicaragua have each articulated their visions for poverty reduction in a public document known as a poverty reduction strategy paper (PRSP). A PRSP describes the macroeconomic, structural, and social policies that a country will implement to foster growth and reduce poverty under a three-year economic adjustment programs supported by PRGF resources. Nicaragua's PRSP is available via the Internet: http://www.imf.org/External/NP/prsp/2001/nic/01/index.htm. Honduras' PRSP is available via the Internet: http://www.imf.org/Externa/NP/prsp/2001/hnd/01/index.htm
} 
Table 3. Returns to Education for Male Workers (In percent)

\begin{tabular}{lcccc}
\hline & Year & Primary & Secondary & Tertiary \\
\hline Costa Rica & 1998 & 6 & 6 & 19 \\
Guatemala & 1998 & 8 & 13 & 14 \\
El Salvador & 1998 & 5 & 8 & 20 \\
Nicaragua & 1998 & 9 & 13 & 15 \\
Panama & 1999 & 6 & 8 & 6 \\
Honduras 2/ & 1997 & $\ldots$ & 3 & 15 \\
Average Central America 1/ & & 7 & & 7 \\
Average Latin America 1/ & & 7 & 4 & 11 \\
Average OECD 3/ & 2000 & 3 & 11 & 12 \\
\hline
\end{tabular}

Sources: Latin Amcrica: Duryea and Pages (2002) based on individual household surveys. Includes urban workers only. Organization for Economic Cooperation and Development: OECD Economic Outlook 70 (2001).

1/ Excluding Honduras for primary and secondary education.

2/ The estimates for Honduras are from Corbacho (2001), and include both males and fernales. The methdology and control variables may not be fully comparable to Duryea and Pages (2002).

3/ OECD denotes the Organization for Economic Cooperation and Development

and probability of employment. Bedi and Marshall (1999) find that, for the case of Honduras, investment in teacher quality has a positive significant effect on student academic achievement, as do smaller class sizes and other classroom and school characteristics.

\section{Trends in educational attainment}

Despite considerable improvement, educational attainment in Central America is one of the lowest in the world, after sub-Saharan Africa and South Asia. Progress was slow during the 1960s; it accelerated in the 1970 s and 1980 s, and continued at a moderate pace during the1990s. The average number of years of education in the adult population doubled, from 2.5 years in the 1960 s to 5 years in 2000 , and the percentage of population with no formal schooling decreased from nearly 50 percent in the 1960 s to around 27 percent in 2000 (Table 4).

The increase in the average educational attainment has been achieved mostly by promoting higher levels of education. The percentage of the population with complete primary education has remained fairly constant since the $1960 \mathrm{~s}$, while the percentage of the population with higher education has increased more than eight times. Among developing countries, Central America currently has the largest share of population with complete postsecondary schooling. Central America exbibits a polarized distribution of education, with a relatively low percentage of population with complete secondary education, but relatively large shares at initial and high levels of education (Table 4). Gender discrepancies have generally declined in Central America. This is in line with the experience of the Latin American region as a whole. Despite the regional progress, gender inequality in education still remains large in Guatemala (Barro and Lee, 2000). 
Table 4. Educational Attainment in Central America and Other Regions

\begin{tabular}{|c|c|c|c|c|c|c|c|c|c|}
\hline & & \multicolumn{7}{|c|}{ Highest Level Attained } & \multirow{3}{*}{$\begin{array}{c}\text { Average } \\
\text { Years } \\
\text { of }\end{array}$} \\
\hline & & \multirow{3}{*}{$\begin{array}{c}\text { No } \\
\text { Schooling }\end{array}$} & \multicolumn{2}{|c|}{ First level } & \multicolumn{2}{|c|}{ Second Level } & \multicolumn{2}{|c|}{ Post-Secondary } & \\
\hline & & & Total & Complete & Total & Complete & Total & Complete & \\
\hline & & & \multicolumn{6}{|c|}{ (Percentage of the population aged 25 and over) } & Schooling \\
\hline \multicolumn{10}{|l|}{ Central America } \\
\hline & 1960 & 48.6 & 44.1 & 12.5 & 5.9 & 1.9 & 1.5 & 1.0 & 2.5 \\
\hline & 1970 & 46.3 & 43.1 & 9.0 & 8.1 & 3.0 & 2.5 & 1.7 & 2.7 \\
\hline & 1980 & 36.7 & 48.4 & 12.3 & 10.1 & 4.2 & 4.8 & 3.3 & 3.5 \\
\hline & 1990 & 30.8 & 47.1 & 12.2 & 13.0 & 5.9 & 9.0 & 6.1 & 4.4 \\
\hline & 1995 & 28.3 & 47.8 & 12.3 & 13.5 & 6.0 & 10.5 & 7.2 & 4.7 \\
\hline & 2000 & 26.6 & 47.3 & 12.2 & 14.0 & 6.1 & 12.1 & 8.2 & 5.0 \\
\hline Costa Rica & & 9.4 & 60.7 & 13.6 & 11.3 & 4.7 & 18.6 & 12.7 & 6.0 \\
\hline Dominican Republic & & 25.7 & 46.8 & 10.3 & 13.1 & 4.7 & 14.5 & 9.8 & 5.2 \\
\hline El Salvador & & 35.0 & 45.6 & 10.1 & 8.8 & 3.7 & 10.6 & 7.2 & 4.5 \\
\hline Honduras & & 25.9 & 57.0 & 12.4 & 10.6 & 6.0 & 6.5 & 4.4 & 4.1 \\
\hline Nicaragua & & 31.7 & 43.0 & 9.5 & 16.5 & 4.8 & 8.9 & 6.0 & 4.4 \\
\hline Panama & & 11.4 & 40.4 & 21.0 & 28.5 & 16.1 & 19.8 & 13.5 & 7.9 \\
\hline \multicolumn{2}{|l|}{ Latin America and the Caribbean } & 17.7 & 50.6 & 14.4 & 19.9 & 8.4 & 11.8 & 7.7 & 5.7 \\
\hline \multicolumn{2}{|l|}{ Middle East and North Africa } & 32.0 & 29.6 & 10.2 & 29.5 & 10.2 & 8.8 & 3.4 & 5.4 \\
\hline \multicolumn{2}{|l|}{ Sub-Saharan Africa } & 42.8 & 38.1 & 8.3 & 17.0 & 2.5 & 2.2 & 0.9 & 3.5 \\
\hline \multicolumn{2}{|l|}{ East Asia and Pacific } & 19.8 & 35.8 & 18.1 & 32.7 & 14.8 & 11.7 & 5.0 & 6.7 \\
\hline \multicolumn{2}{|l|}{ South Asia } & 45.2 & 28.2 & 10.0 & 22.9 & 7.0 & 3.7 & 2.0 & 4.6 \\
\hline \multicolumn{2}{|l|}{ Transitional Economies } & 2.2 & 32.4 & 20.2 & 51.6 & 17.4 & 13.9 & 9.4 & 9.7 \\
\hline
\end{tabular}

Source: Barro and Lee (2000).

\section{Indicators of quality and quantity of educational inputs}

Taken as a whole, the available indicators of input quality and quantity in Central America do not present a promising picture. Lack of resources and inefficiency are reflected in large dropout and repeater rates. For instance, in 1990, repeater rates in primary education in Central America were 11.6 percent, above the Latin American average of 10.5 percent. In fact, Central America exhibited the largest repeater rate in primary education after sub-Saharan Africa. Dropout rates in primary school in Central America are over 55 percent, well above the Latin American average of 37 percent. Dropout rates have even increased since the $1980 \mathrm{~s}^{16}$

\section{Government spending on education}

As a share of GDP, government spending on education in Central America is slightly below the rest of Latin America. From 1990 to 1996, spending in Central America averaged less than 3 percent of GDP; for Latin America as a whole, spending averaged

\footnotetext{
${ }^{16}$ See Corbacho and Davoodi (2002) for further details.
} 
slightly more than 3 percent of GDP. Within the Central American countries, spending ranged from 1.6 percent of GDP in Guatemala to 5.2 percent in Panama in 1996 (Table 5). In the mid 1990s, all countries allocated over 90 percent of total education expenditures to current spending, with the exception of Nicaragua, which allocated over 80 percent (World Development Indicators, 2002).

Table 5. Government Education Spending

(In percent of GDP)

\begin{tabular}{lrrrrrrrrr}
\hline \multicolumn{2}{l}{ Year Costa Rica } & $\begin{array}{c}\text { Dominican } \\
\text { Republic }\end{array}$ & $\begin{array}{c}\text { El } \\
\text { Salvador }\end{array}$ & Guatemala & Honduras & Nicaragua & Panama & $\begin{array}{c}\text { Central } \\
\text { America }\end{array}$ & $\begin{array}{c}\text { Latin } \\
\text { America }\end{array}$ \\
\hline & & & & & & & & & \\
1985 & 4.1 & 1.5 & $\ldots$ & 1.5 & 4.0 & $\ldots$ & 4.4 & $\ldots$ & 3.1 \\
1990 & 4.4 & $\ldots$ & 1.9 & 1.4 & $\ldots$ & 3.4 & 4.7 & $\ldots$ & 2.8 \\
1991 & 3.4 & $\ldots$ & 1.8 & 1.3 & 3.8 & 3.4 & 4.6 & 3.1 & 3.0 \\
1992 & 3.3 & 1.3 & 1.9 & 1.4 & $\ldots$ & 3.1 & 5.0 & 3.0 & 3.1 \\
1993 & 3.5 & 1.6 & 1.8 & 1.5 & $\ldots$ & 2.8 & 4.7 & 2.7 & 2.9 \\
1994 & 3.5 & 1.9 & 2.0 & 1.5 & 3.4 & 2.8 & 4.5 & 2.8 & 3.3 \\
1995 & 3.5 & 1.9 & 2.2 & 1.7 & 3.6 & 3.1 & 5.0 & 3.0 & 3.3 \\
1996 & 4.1 & 1.9 & 2.3 & 1.6 & $\ldots$ & 3.2 & 5.2 & 3.0 & 3.3 \\
1997 & $\ldots$ & 2.2 & 2.5 & $\ldots$ & $\ldots$ & 3.7 & 5.0 & $\ldots$ & $\ldots$ \\
1998 & 6.0 & $\ldots$ & $\ldots$ & 2.0 & 4.0 & 4.2 & $\ldots$ & $\ldots$ & $\ldots$ \\
\hline
\end{tabular}

Source: World Bank, 2002, World Development Indicators (Washington).

\section{Based on simple calculations, the efficiency of public education spending in Central America appears to be somewhat lower than the average for developing countries.} Figure 1 plots the illiteracy rate against primary-school spending per student, controlling for GDP per capita. ${ }^{17}$ The objective is to analyze the extent to which additional spending per student at the primary level leads to higher achievement, over and above the effect of higher income and all the other socioeconomic variables correlated with it. The regression explains almost 70 percent of the variation in illiteracy, and both independent variables are statistically significant. A one percent increase in spending is estimated to reduce illiteracy by almost one percent. While this regression is indicative at best, it does imply that efficiency is lower in Central American than in the other developing countries in the sample. ${ }^{18}$ The

${ }^{17}$ The data are from World Development Indicators 2002. Spending and income were measured on a PPP basis. Logarithmic transformations were applied to all variables. The regression should either have adjusted for enrollment rates or included them as another independent variable. This was not done, because too many observations would be lost. Enrollment rates in Central America all fall within a 10 percentage point range, however.

${ }^{18}$ These findings are in line with those of Gupta, Honjo, and Verhoeven (1997). They find that government education spending is relatively efficient in Latin America. However, while in the mid-1980s Latin America had better efficiency indicators than Asia, the relative performance of Latin America subsequently declined while that of Asia improved. Within the Latin American region, Guatemala, Honduras, and Nicaragua are found to be relatively inefficient. When looking at the subsample of higher-income countries, Costa Rica appears to be relatively inefficient, when compared to Argentina, Colombia, and Mexico. 
residuals are positive - i.e., illiteracy is higher than would be predicted by the regressionfor Costa Rica, the Dominican Republic, El Salvador, Guatemala, and Nicaragua (the other two subject countries were not in the regression sample). ${ }^{19}$

Figure 1. Relationship Between Illiteracy Rate and Spending on Education

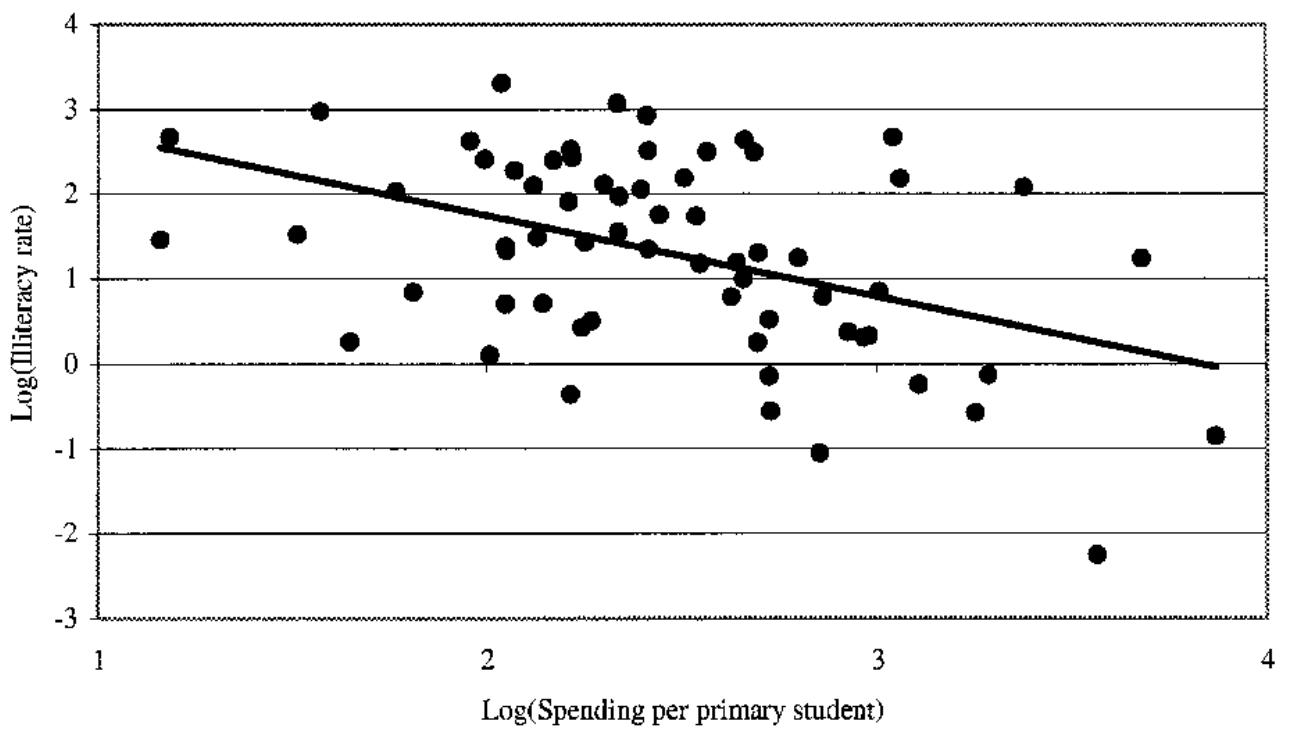

Available evidence shows that education spending is well targeted towards the poor in only three countries. The limited studies of benefit incidence of education spending show that the poorest 20 percent of income distribution in Costa Rica, the Dominican Republic, and Honduras benefit more than the richest 20 percent, while in Nicaragua and Panama the rich capture more of the benefits than the poor (Figure 2). Nicaragua's situation is rather extreme, whereby 40 percent of benefits are captured by the top 20 percent, as compared with 9 percent by the bottom 20 percent. In general, tertiary education seems to benefit primarily the well-to-do (Chu, Gupta, and Davoodi, 2000), evidence that is consistent with trends in educational attainment for higher education in the region.

\section{Teacher salaries and teacher quality}

Teacher wages in Central America are high by regional standards. For instance in 1990, the average real salary of primary school teachers was four times GDP per capita in Central America, compared to 2.6 times GDP per capita in Latin America. The average ratio in

${ }^{19}$ Gupta, Verhoeven, and Tiongson (2002) analyze the effects of increased allocations of government spending for primary and secondary education. They find that a 5 percentage point increase in the share of education spending devoted to primary and secondary education increases gross secondary enrollment by over one percentage point. However, the authors stress that increasing attainment through reallocations alone can be difficult, as it is also necessary to improve other key determinants of educational outcomes. 
Figure 2. Benefit Incidence of Public Spending on Education, 1990s (In percent of total spending)

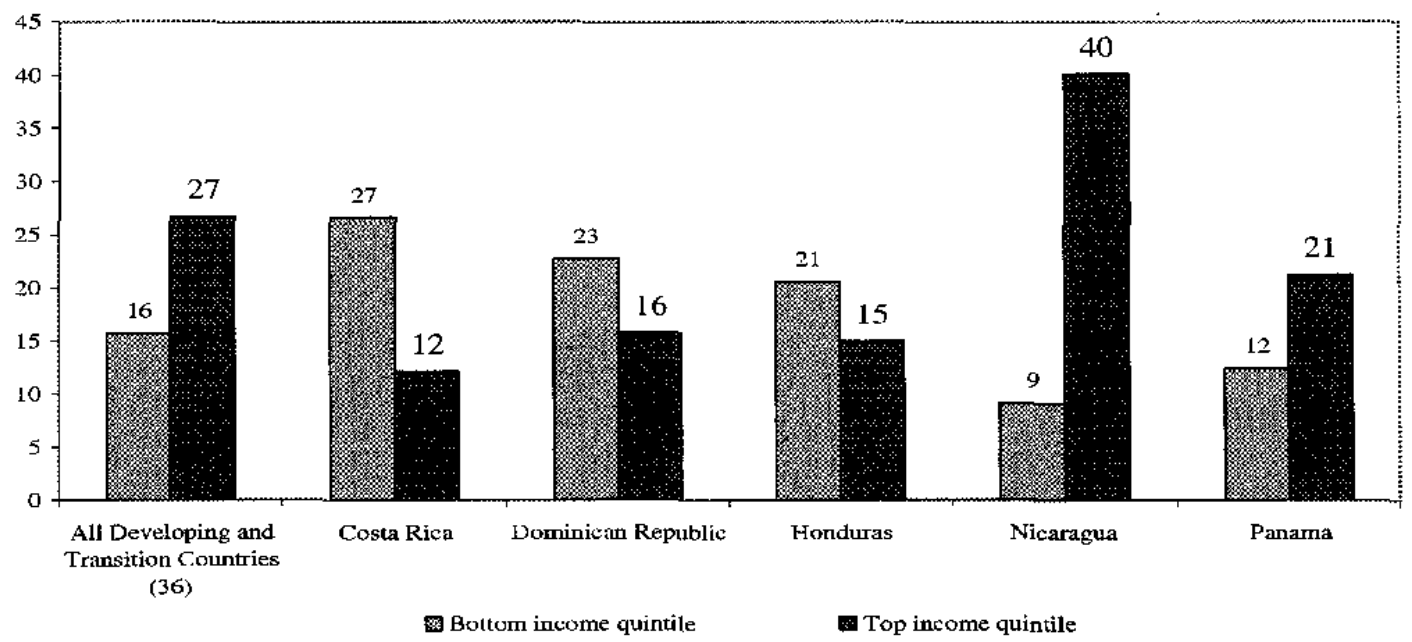

Central America is also higher than the average of 3.6 for all developing countries (Barro and Lee, 1996), and has increased consistently since the 1960s. Within the Central American region, Nicaragua and Honduras exhibit the largest ratio of primary school teacher wages to GDP per capita, 5.7 and 4 respectively. ${ }^{20}$

A recent study of 12 Latin American countries (including Costa Rica, El Salvador, Honduras, and Panama) finds that compensation of school teachers in the region is higher than compensation for workers with similar characteristics in other professions. Using household survey data, Liang (1999) finds that teachers are paid less than nonteachers when not controlling for work time. However, teachers work significantly less than others, about 15 hours per week. ${ }^{21}$ When controlling for work and vacation time, wages for teachers are actually higher than for workers with similar characteristics in 11 out of the 12 cases under study. Also, disparities in teacher pay are lower than in other professions and rural teachers are paid on average 10 to 30 percent less than urban teachers. Within Central America, teachers in Honduras earn 44 percent more per hour worked than nonteachers. This premium is 38 percent in Costa Rica, 37 percent in El Salvador, and 33 percent in Panama. In addition, public school teachers are paid more than private school teachers in El Salvador, Honduras, and Panama (the opposite occurs in South America).

\footnotetext{
${ }^{20}$ Based on Barro and Lee (1996). See Corbacho and Davoodi (2002) for further details.

${ }^{21}$ Given the low average workload, it is common for teachers to hold other positions. It is estimated that 90 percent of the teachers in El Salvador and more than half of the teachers in Guatemala have other jobs (Alvarez and Majmudar, 2001).
} 
Higher wages need not guarantee higher quality. Evaluating the relationship among pay, quality, and performance is problematic at best. Hanushek, Kain, and Rivkin (1999), using data from the UTD Texas School Project, find that salaries are only weakly related to performance on teacher certification tests, but teacher certification tests are not related to student achievement. The study does find a relationship between teacher salaries and students' math and reading performance, but only for existing experienced teachers. For northeast Brazil, Harbison and Hanushek (1992) conclude that teacher wages are not significantly related to education outputs. Gupta, Honjo, and Verhoeven (1997) find a negative significant relationship between the efficiency of education spending and relative government wages. Consequently, countries with relatively higher teacher wages incur larger costs, but may not achieve significantly higher educational attainment, than countries with relatively lower teacher wages.

Teacher quality has been identified as a key input in student learning. ${ }^{22}$ The level of training for teachers varies significantly among the countries in Central America. Teachers in Costa Rica, El Salvador, and Panama all receive tertiary education. On the other hand, teachers in Guatemala, Honduras and Nicaragua are trained in normal schools, which are similar to secondary schools. Close to one third of teachers in Nicaragua are uncertified. The percentage of uncertified teachers in the other countries is less significant (Alvarez and Majmudar, 2001).

\section{Student-teacher ratios and schooling time}

Student-teacher ratios in primary and secondary education in Central America are above Latin American averages and have increased since the $1960 \mathrm{~s} .{ }^{23}$ It is not surprising that Panama and Costa Rica have the lowest student-teacher ratios. On the other hand, the historically low student-teacher ratios in secondary schools in Guatemala and Honduras warrant additional analysis. The threshold question, however, is whether reductions in the generally high student-teacher ratios would be the best use of resources in Central America.

In the majority of Latin American countries, schooling time in primary education is low, both in terms of days and hours per year. Additionally, a large share of the already

\footnotetext{
${ }^{22}$ For instance, studies for the U.S. show that 40 percent of the variance in test scores in reading and mathematics in schools in Texas was explained by the qualification of teachers (Fergusson, 1991). Hanushek, Kain, and Rivkin (1998) also present evidence that a better quality of teachers can have powerful effects on academic achievement. Similar results have been found in Alabama, New York City, Michigan, Georgia, and Virginia. For the case of Honduras, Bedi and Marshall (1999) find that improvements in teacher quality have a significant effect on student achievement tests.

${ }^{23}$ Smaller class sizes have generally been associated with better student performance. For example, Krueger and Whitmore (2000) and Krueger (2002) estimate that a reduction in class size from 22 to 15 students in elementary schools in Tennessee has an internal rate of return of around 6 percent. Also, students in small classes are likely to perform better on standardized tests at the eighth grade level and are more likely to take college entry exams.
} 
low schooling time is spent on administrative duties and disciplinary actions and less on curriculum teaching per se. This affects low-income children in particular who cannot compensate for these shortages with family inputs (Martinic, 1998). Scheduled schooling time in Central America, however, is higher than in Latin America as a whole, but teacher union conflicts and strikes severely diminish the effective number of school days students have. For instance in 2001, teachers were on strike for two months in Honduras, in response to a dispute over wages with the central government.

\section{B. Provision of Health Services}

\section{Returns to investment in health}

Aside from their (arguably more important) effect on general quality of life, investments in health care can increase human capital and enhance productivity. Studies have found that health has a positive impact on earnings, although the magnitude of the effect depends on the health measure, the particular sample, and the estimation method used in the analysis. ${ }^{24}$ Although case studies are scarce for Central America, Espinosa and Hernandez (2000) conclude that better housing conditions and the availability of community and health services have a significant effect on health status in Nicaragua. Furthermore, better health status is associated with higher hourly income, on average. The point estimates in this study are much larger than in studies of higher-income countries (Savedoff and Schultz, 2000), suggesting that investments in health may be even more valuable in developing countries.

\section{Trends in health status}

Progress in health status has been rather fast in Central America. Life expectancy at birth in the region has increased from an average of 54 years in the 1960 s to nearly 70 years in the 1990s (Table 6). Reductions in infant and child mortality rates have played an important role in this increase. Improvements in health status in Central America have even been faster than for Latin America as a whole. Part of the explanation may reside in the relatively large investments in girls' education compared to other developing regions; women's educational attainment has been shown to be an important contributing factor to improved health status (Savedoff and Schultz, 2000).

There are still marked disparities in health status across Central America. Costa Rica has health status indicators that are comparable to or better than some developed countries. Panama also has very good health indicators. On the other hand, health development in other countries is still lagging, particularly in Guatemala, Nicaragua, and Honduras. It should be

\footnotetext{
${ }^{24}$ These studies show that public health services and community characteristics, as well as private health inputs and reduced exposure to disease, are associated positively with the health of adults and with greater incomegenerating capacity (Savedoff and Schultz, 2000).
} 
Table 6. Trends in Health Status 1/

\begin{tabular}{|c|c|c|c|c|c|c|c|c|c|}
\hline Year & Costa Rica & $\begin{array}{c}\text { Dominican } \\
\text { Republic }\end{array}$ & El Salvador & Guatemala & Honduras & Nicaragua & Panama & Central America & Latin America \\
\hline \multicolumn{10}{|c|}{ Infant Mortality Rate (in percent) } \\
\hline 1960 & 67.5 & 113.7 & 119.2 & 122.9 & 130.5 & 126.2 & 59.8 & 105.7 & 97.5 \\
\hline 1970 & 39.8 & 91.1 & 101.5 & 98.9 & 96.3 & 96.4 & 40.7 & 80.7 & 75.8 \\
\hline 1980 & 17.4 & 65.9 & 69.6 & 74.2 & 62.5 & 75.0 & 29.7 & 56.3 & 53.5 \\
\hline 1990 & 13.3 & 42.6 & 36.5 & 46.7 & 41.6 & 42.0 & 23.0 & 35.1 & 34.8 \\
\hline 1999 & 12.4 & 38.9 & 30.1 & 40.2 & 34.4 & 34.3 & 20.2 & 30.1 & 30.0 \\
\hline \multicolumn{10}{|c|}{ Child Mortality Rate (in percent) } \\
\hline 1960 & 112.0 & 149.0 & 210.0 & 202.0 & 204.0 & 209.0 & 104.0 & 170.0 & 154.1 \\
\hline 1970 & 77.0 & 111.5 & 160.0 & 168.0 & 170.0 & 168.0 & 71.0 & 132.2 & 123.5 \\
\hline 1980 & 29.0 & 77.7 & 120.0 & 109.7 & 103.0 & 143,0 & 36.0 & 88.3 & 79.9 \\
\hline 1990 & 14.9 & 50.9 & 43.0 & 59.0 & 54.4 & 52.3 & 25.4 & 42.8 & 42.8 \\
\hline 1999 & 14.0 & 46.8 & 36.0 & 52.0 & 46.0 & 43.0 & 25.0 & 37.5 & 38.0 \\
\hline \multicolumn{10}{|c|}{ Life Expectancy at birth (in ycars) } \\
\hline 1960 & 63.8 & 54.5 & 53.4 & 48.0 & 48.9 & 49.6 & 62.6 & 54.4 & 57.9 \\
\hline 1970 & 69.0 & 60.4 & 57.6 & 54.2 & 55.2 & 55.8 & 67.3 & 59.9 & 62.1 \\
\hline 1980 & 73.9 & 63.6 & 59.6 & 58.6 & 62.7 & 60.4 & 71.0 & 64.3 & 66.0 \\
\hline 1990 & 76.1 & 67.2 & 68.0 & 63.3 & 68.5 & 66.9 & 73.4 & 69.1 & 69.0 \\
\hline 1999 & 76.8 & 67.3 & 69.5 & 64.9 & 69.8 & 68.6 & 73.9 & 70.1 & 69.8 \\
\hline
\end{tabular}

Source: World Bank, 2002, World Development Indicators (Washington); and Fund staff estimatcs.

1/ Average for the available years in each decade.

noted, however, that even the lagging countries have made important progress in improving health outcomes over time.

There are important differences in the health status of the poor versus the nonpoor in the region; also, health status in rural areas is generally worse than in urban areas. ${ }^{25}$ For example in Nicaragua and the Dominican Republic, infant mortality rates have been reported to be more than 20 percentage points higher among poor households than rich households. In Guatemala, mortality rates for the poor are more than 10 percentage points higher than the rates for the nonpoor. ${ }^{26}$ In Nicaragua, there is evidence that poor children exhibit larger

\footnotetext{
${ }^{25}$ For instance in Guatemala, infant mortality per 1,000 live births is only 18 in urban areas but rises to 29 in rural areas and 32 among indigenous populations. In Honduras, in addition to poorer infrastructure and lower income, there are evident deficiencies in medical attention in rural areas, due to lack of both medical supplies and doctors (Honduras' PRSP). Wang (2001), in a study including the Dominican Republic, El Salvador, Guatemala and Nicaragua, concludes that factors affecting child mortality rates differ between urban and rural areas. In urban areas, access to electricity has been singled out as a key determinant of health outcomes for children and infants. In rural areas, expanding vaccination numbers is found to reduce significantly mortality rates.

${ }^{26}$ See Corbacho and Davoodi (2002) for further statistics.
} 
malnourishment rates than the nonpoor and report illness with 50 percent greater frequency (Nicaragua's PRSP). These discrepancies are lower than for the Latin American average and highlight the importance of improved health infrastructure-e.g., sanitation and clean water-and nutrition on health.

\section{Health quality indicators}

\section{Organization of health systems}

Health systems in all Central American countries, with the exception of Costa Rica, are characterized by rigidity and fragmentation. The organization of the financing scheme makes resource allocation complicated, with detrimental effects on quality. The staff of medical facilities usually has limited capacity to decide the allocation of expenditures within the hospital and consequently there are important mismatches between needs and resources and an emphasis on curative over preventive health care (Inter-American Development Bank, 1996).

Public facilities are of generally poor quality. For example in Nicaragua, studics by the Inter-American Development Bank and the World Bank found that health facilities were generally in bad condition due to lack of maintenance, with over 70 percent of health posts requiring rehabilitation. In El Salvador, users consistently complained about the low quality of public health posts and units, especially relative to higher levels of services from health centers and hospitals (Filmer, Hammer, and Pritchett, 1998). In the Dominican Republic, the Inter-American Development Bank estimated that over 30 percent of the hospitals are underutilized (Inter-American Development Bank, 1996). Finally, there are large discrepancies between expenditures on personnel and the actual staff costs of treating patients, and no accountability for performance or effective management (Filmer, Hammer, and Pritchett, 1998). In spite of these characteristics, the health system in Costa Rica is considered equitable and efficient (Inter-American Development Bank, 1996).

Medical staff is generally in excess supply in Central America. In the Dominican Republic, the workload has been reduced to three hours per day. In Nicaragua, doctors are required to serve very few hours. In Costa Rica, nearly 40 percent of nurses of the public system can be on leave at the same time. Finally, the absenteeism rate among doctors is high in Panama (Inter-American Development Bank, 1996).

\section{Government spending on health}

Central America as a region invests a relatively large share of GDP in health. In 1998, total expenditures on health averaged 6.5 percent of GDP, roughly the same as Latin America as a whole. Of this, 3.6 percent of GDP came from public resources-again similar to Latin America as a whole - and the remainder was financed privately (Table 7). Only Guatemala and the Dominican Republic allocated less than 3.2 percent of GDP to public health spending. 
Table 7. Government and Private Health Expenditures (In percent of GDP)

\begin{tabular}{|c|c|c|c|c|c|}
\hline & \multicolumn{2}{|c|}{ Public Spending } & \multicolumn{2}{|c|}{ Private Spending } & \multirow[b]{2}{*}{ Total } \\
\hline & Social security & Other & Insurance & Other & \\
\hline Costa Rica & 4.7 & 0.8 & 0.0 & 1.5 & 6.8 \\
\hline Dominican Republic & 0.5 & 1.4 & 1.1 & 3.6 & 6.5 \\
\hline El Salvador & 1.7 & 1.5 & 0.2 & 4.6 & 8.3 \\
\hline Guatamala & 1.3 & 0.7 & 0.2 & 2.2 & 4.4 \\
\hline Honduras & 0.6 & 3.0 & 0.2 & 2.3 & 6.4 \\
\hline Nicaragua & 1.2 & 2.2 & $\ldots$ & 2.1 & 5.7 \\
\hline Panama & 3.2 & 2.0 & 0.5 & 1.8 & 7.5 \\
\hline Central America & 1.9 & 1.7 & 0.3 & 2.6 & 6.5 \\
\hline Latin America & 1.8 & 1.6 & 0.7 & 2.3 & 6.6 \\
\hline
\end{tabular}

Source: World Health Organization (2001).

The relationship between public health spending and health indicators is weaker than might be expected. Figure 3 plots child mortality rates against government health spending per capita, again controlling for GDP per capita. ${ }^{27}$ The regressions on which the figure is based explain more than 80 percent of the variation in mortality rates. They indicate that a one percent increase in government spending will decrease mortality by slightly more than one tenth of a percent. More important-since it is impossible to assess without more information whether the effect on mortality along with other effects of higher spending would be cost effective- the coefficient on public spending is only roughly $1 \frac{1 / 2}{2}$ times its standard error in each of the regressions.

Public health spending matters as the health status of the poor is more sensitive to public spending than that of the rich. A study by Gupta, Verhoeven, and Tiongson (2001), which includes all the countries under the present analysis, finds that the poor have significantly worse health status than the nonpoor and that the poor are more strongly affected by public spending on health than the nonpoor. For child mortality rates, the authors find that a one percent increase in public spending on health reduces child mortality by twice as many deaths among the poor. In addition, they find some evidence that the returns to public spending on health are higher among the poor regardless of the benefit incidence. Also, the relationship between public spending in health care and the health status of the poor is stronger among low-income countries.

Health spending is well targeted in three out of the four countries for which data are available. The limited studies of benefit incidence of health spending show that the poorest 20 percent of income distribution in Costa Rica, the Dominican Republic and Honduras

\footnotetext{
${ }^{27}$ The mortality and income variables are from World Development Indicators. The health spending data were compiled by the World Health Organization. Spending and income data are measured on a PPP basis. Logarithmic transformations were applied to all variables.
} 
Figure 3. Relationship between Child Mortality Rates and Government Health Spending

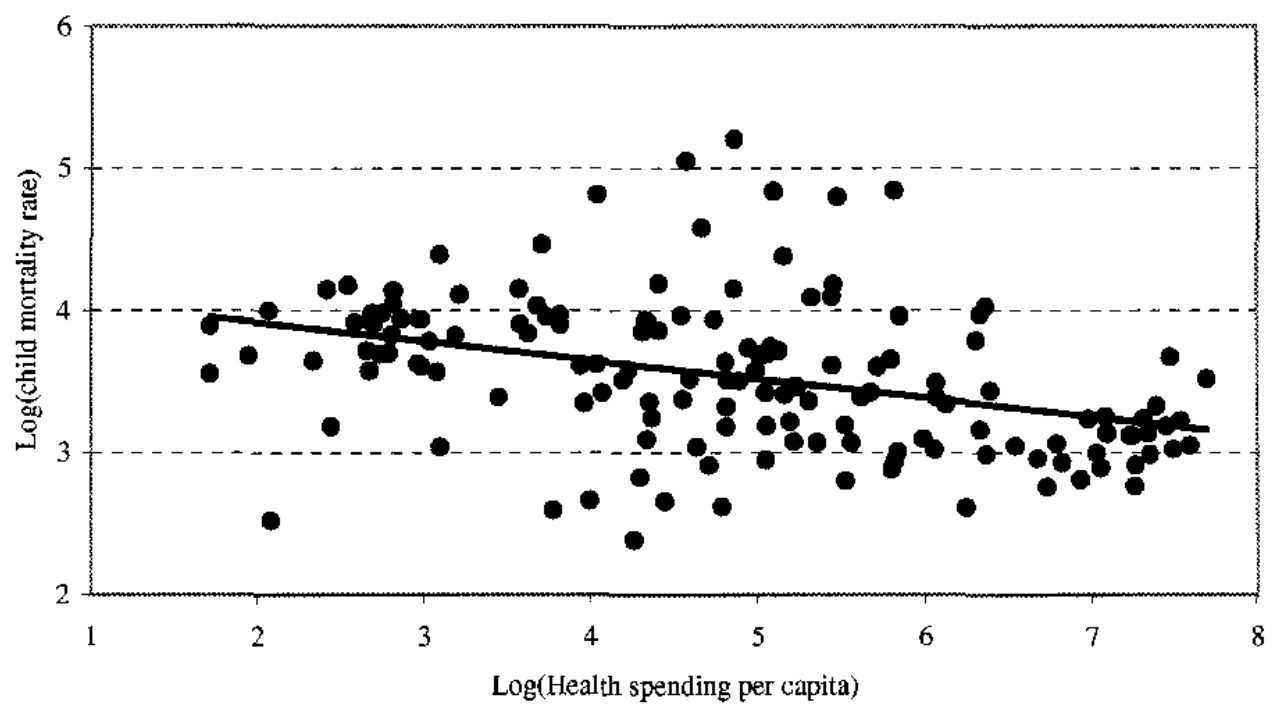

benefit more than the richest 20 percent, while in Nicaragua the richest 20 percent benefit more from health spending, as was the case in the education sector (Figure 4). Much like the incidence of education spending, Nicaragua's incidence of health spending is rather extreme vis-à-vis other countries; 25 percent of benefits are captured by the richest 20 percent as compared with 10 percent by the poorest 20 percent.

\section{Other quality characteristics}

While quality indicators for health have generally improved in the region, marked differences still remain across countries. For example, in the 1990s the percentage of births attended by health staff was 97 percent in Costa Rica, but only 35 percent in Guatemala and 51 percent in Honduras. There has been a considerable improvement in immunization rates. For example, in the case of immunization against measles, all countries reached rates over 90 percent during the 1990s. ${ }^{28}$ Immunization against illness, in turn, has been shown to be very effective for poverty reduction.

There is also evidence that the poor have less access to good health care. In Nicaragua, the extremely poor must travel three times the distance to reach health facilities than nonpoor households have to. Poor children in Nicaragua, besides reporting greater frequency of illness, have half the access to doctors when sick, compared to the nonpoor. Also, extremely

\footnotetext{
${ }^{28}$ Based on Barro and Lee (1996). See Corbacho and Davoodi (2002) for further details.
} 
Figure 4. Benefit Incidence of Public Spending on Health, 19\%( $\mathrm{s}^{1}$

(In percent of total spending)

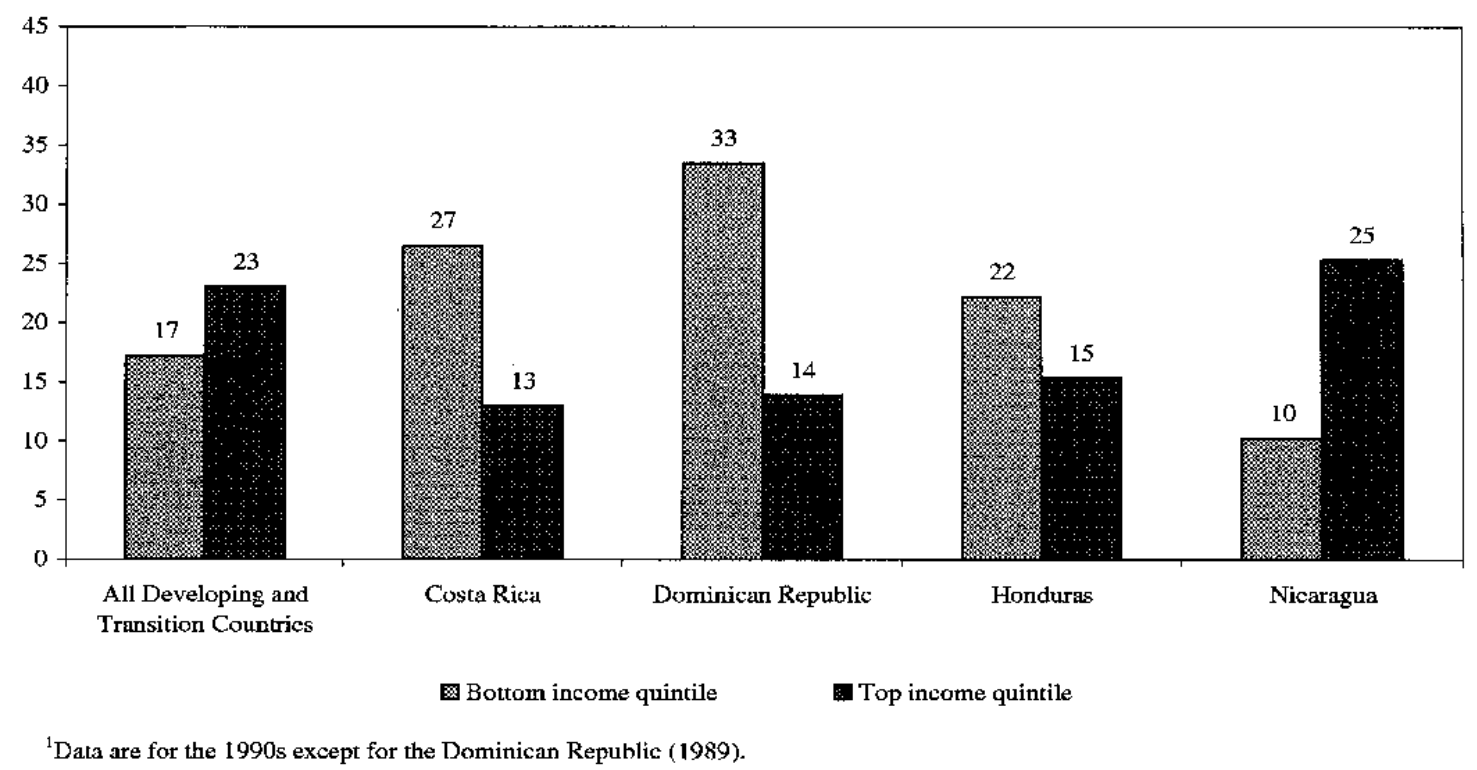

poor women are half as likely as nonpoor women to be attended by doctors when giving birth (Nicaragua's PRSP).

\section{Social SAFETY NeTS}

Economic downturns-especially those that lead to financial crises-can result in increased poverty and unemployment and their attendant social problems. A wide range of available instruments can be used to assist the poor in the event of an economic crisis. Instruments for managing adverse shocks can be classified in three categories (InterAmerican Development Bank, 2000). First, there are market-based arrangements such as financial intermediaries and insurance companies, allowing households to smooth income and consumption over time. Second, the government provides public insurance to protect against unemployment and illness, and safety nets to focus on the special needs of the poor. Finally, there are informal self-insurance mechanisms arranged through extended families and social networks. Although informal safety nets play an important role in providing social protection for the poor, their effectiveness is limited and they are imperfect substitutes for formal safety nets. Major social safety nets may include cash or in-kind transfers, price subsidies, public works, fee waivers for social services, feeding and nutrition programs, targeted human development and microfinance programs, as well as social insurance targeted to the poor.

Effective social safety nets should provide appropriate protection for the poor, promote efficient targeting, and avoid counterproductive incentives. They should also be well managed and transparent, operating within a sound fiscal and macroeconomic framework. 
The key objectives of a social protection program should be to (1) guarantee a minimum consumption level and access to basic services, to prevent temporary poverty from becoming permanent; (2) strengthen the asset base of the poor to reduce their vulnerability to shocks and prevent the intergenerational transfer of poverty; (3) ensure continued investment in human capital; and (4) reduce the risk exposure of the poor (Inter-American Development Bank, 2000).

The design of safety nets should reflect the characteristics and location of poor populations and the administrative and implementation capacity of the government. Ideally, safety net instruments should be in place before a crisis occurs. When this is not possible, social safety nets should focus on those existing programs that can be easily targeted to the poor and adapted for increased utilization during adverse economic shocks. Governments should make every effort to protect and even increase social spending and allocations for social safety nets in the event of a crisis.

Latin America does not have adequate prevention and compensation systems to reduce the effects of shocks on the poor (Inter-American Development Bank, 2000). In the absence of reforms that address the needs of the most vulnerable groups, macroeconomic shocks will continue to exacerbate poverty and inequality and curtail growth.

Central American countries have a number of social safety net mechanisms in place. These can be grouped in three main categories: food and cash transfers, targeted human development programs, and employment and infrastructure programs. Costa Rica, El Salvador, Honduras, Nicaragua and Panama have at least one program in each category. Social safety nets in the Dominican Republic, on the other hand, focus exclusively on food and cash transfers. Guatemala has a school lunch program and several infrastructure programs but no targeted human development programs. ${ }^{29}$

The high levels of poverty and inequality suggest that governments could do more in reaching and protecting the most vulnerable groups of society. In this sense, it is crucial that the existing programs have good evaluation mechanisms, so that governments identify and support those programs that are effective for poverty reduction and discontinue those that are ineffective. Clearly, better targeting of social safety nets and preventing leakage to nonpoor populations is crucial in this matter. The urban-rural differences in access to basic infrastructure and the large size of the informal labor market present difficult challenges, ${ }^{30}$ and governments should therefore put particular emphasis on reaching the rural poor. Also, social safety nets in Central America should aim at providing protection against adverse economic shocks, and even more against natural disasters that occur in the region. As mentioned before, precrisis planning is essential.

\footnotetext{
${ }^{29}$ See Corbacho and Davoodi (2002) for further detail on specific programs.

${ }^{30}$ Corbacho (2000) finds that the size of the informal sector in Central America is very large, exceeding 40 percent of total employment, and grew in most countries during the $1990 \mathrm{~s}$.
} 


\section{GOVERNANCE}

Governance is an all-encompassing term with wide ranging implications for improving the performance of the public sector. Governance typically refers to

...traditions and institutions by which authority is exercised which tend to include (i) the process by which governments are selected, monitored and replaced; (ii) the capacity of the government to effectively formulate and implement policies, and (iii) the respect of citizens and the state for the institutions that govern economic and social interactions among them (Kaufmann, Kraay, and Zoido-Lobatón, 2002).

This definition applies mostly to the public sector and has been used widely in the literature on governance. But the east Asian crisis of the late 1990s and the collapse of large corporations (e.g., Enron in 2001) demonstrate that corporate governance does matter as well, and that part of promoting governance in the public sector is to provide appropriate regulation and oversight of the private sector.

Transparency in operation of the public sector can improve governance. Adherence to the IMF's Code of Fiscal Transparency and quality of fiscal data is one way to promote transparency. Countries voluntarily collaborate with the IMF in drafting a Report on the Observance of Standards and Codes (ROSC) for public administration. The report assesses performance against a slate of best practices in fiscal management. As of June 2002, Nicaragua and Honduras are the only countries in Central America that have a completed fiscal ROSC posted on the IMF web site, but ROSCs for other countries are underway. Both countries have made good progress in improving fiscal transparency and their budgets provide more comprehensive information on budget execution. However, there is room for improvement in both countries.

Corruption, transparency, and poor governance are closely related. Corruption can be defined as monopoly plus discretion minus accountability. Other reformulations are possible. Therefore corruption varies directly with the degree of monopoly power (government or otherwise) and the level of discretion, and inversely with the degree of accountability. Appropriate reforms in these directions will tend to decrease corruption.

Corruption can have a large impact on the provision of public services, particularly on education services and health care. Reducing corruption improves the efficiency with which public resources are transformed in the public services, thereby resulting in higher school enrollment rates and lower mortality rates (Gupta, Davoodi, and Tiongson, 2001). It can also improve the targeting of existing spending on education and health care (Gupta and others, 2000). For these reasons, it is crucial that governments institute transparent procurement procedures and enhance the financial accountability of public spending. In addition, the capacity to formulate and execute the budget should be strengthened, with a 
larger share of resources allocated to primary education and basic health care, and to reducing the out-of-pocket expenses borne by the poor.

The World Bank has developed new indicators of governance. Recently, measures of governance, created by three World Bank economists, score performance on five dimensions that underlie the definition of governance given earlier. These are (1) voice and accountability, (2) political stability and lack of violence, (3) government effectiveness, (4) rule of law, and (5) control of corruption (Kaufmann, Kraay, and Zoido-Lobatón, 2002).

Based on the above data set, Central America does better than Latin America on three out of six governance indicators (Table 8). These are voice and accountability, political stability, and regulatory quality. For example, in 2000/01, 62 percent of countries had a lower score on voice and accountability than the average score in Central America, compared with 59 percent for Latin America as a whole. By contrast, Central America had lower scores than Latin America as a whole on corruption, rule of law, and effectiveness of government. For example, only 43 percent of countries had lower levels of corruption than Central America, whereas the corresponding number for Latin America is 90 percent. Within Central America, Cost Rica performs the best across all six with at least 70 percent of countries having a lower score in all six categories. In fact, Costa Rica' score is close to the OECD average.

According to these data, Guatemala has the worst rating within Central America on voice and accountability and on political stability, and Honduras, on government effectiveness, regulatory quality, rule of law, and corruption. On average, Central America made significant strides between $1997 / 98$ and $2000 / 01$ in political stability and control of corruption.

Countries in the region have instituted various measures to address governance and corruption. Panama's original anti-money-laundering law has been broadened to include drug-related offenses, proceeds from fraud, extortion, embezzlement, corruption of public officials, kidnapping, and acts of terrorism. In Nicaragua, the comptroller's office is being strengthened; a new procurement law has been adopted, along with the establishment of mediation courts and the approval of a law on dispute settlements. In the Dominican Republic, the treasury system is being strengthened through an integrated financial management program, with assistance from the Inter-American Development Bank. In Guatemala, the existing integrated financial management system is being extended to agencies outside the central government; in addition, laws on probity and procurement are under consideration. 
Tablc 8. Indicators of Governance

\begin{tabular}{|c|c|c|c|c|c|c|c|c|c|c|c|c|}
\hline & \multicolumn{2}{|c|}{ Voice and Accountability } & \multicolumn{2}{|c|}{ Political Stability } & \multicolumn{2}{|c|}{ Government Effectiveness } & \multicolumn{2}{|c|}{ Regulatory Quality } & \multicolumn{2}{|c|}{ Rulc of Law } & \multicolumn{2}{|c|}{ Control of Comuption } \\
\hline & $1997 / 98$ & $200 / 01$ & $1997 / 98$ & $200 / 01$ & $1997 / 98$ & $200 / 01$ & $1997 / 98$ & $200 / 01$ & $1997 / 98$ & $200 \%$ & $1997 / 98$ & $200 \% 01$ \\
\hline Costa Rica & 88 & 91 & 82 & 86 & 74 & 78 & 92 & 85 & 71 & 71 & 77 & 81 \\
\hline El Salvador & so & 62 & 48 & 71 & 45 & 46 & 99 & 87 & 30 & 31 & 43 & 47 \\
\hline Guatemala & 34 & 40 & 22 & 20 & 46 & 31 & 67 & 53 & I1] & 14 & 20 & 29 \\
\hline Honduras & 52 & $\$ 2$ & 37 & 57 & 36 & 33 & 44 & 39 & 17 & 10 & 12 & 32 \\
\hline Nicaragua & 58 & 51 & 39 & 61 & 30 & 28 & 38 & 39 & 26 & 21 & 19 & 24 \\
\hline Рвпаm民 & 71 & 72 & 56 & 70 & 43 & 49 & 94 & 86 & 40 & 53 & 38 & 42 \\
\hline Dominican Republic & 51 & 65 & 55 & 65 & 17 & 46 & 71 & 76 & 65 & 57 & 24 & 50 \\
\hline \multicolumn{13}{|l|}{ Regional averages } \\
\hline Central America & 58 & 62 & 48 & 61 & 42 & 44 & 72 & 66 & 37 & 37 & 33 & 43 \\
\hline Latin Amcrica and the Caribbcan & 60 & 60 & 46 & 54 & 49 & 49 & 67 & 59 & 44 & 46 & 47 & 51 \\
\hline Latin Amcrica & 60 & 59 & 44 & 52 & 50 & 46 & 71 & 60 & 41 & 42 & 42 & 46 \\
\hline OECD I & 92 & 92 & 88 & 90 & 91 & 90 & 87 & 88 & 90 & 90 & 91 & 90 \\
\hline Sub-Saharan Africa & 38 & 36 & 30 & 28 & 35 & 32 & 34 & 36 & 33 & 33 & 37 & 34 \\
\hline Eastem Europe & 61 & 67 & 56 & 55 & 49 & 51 & 54 & 54 & 53 & 57 & so & 54 \\
\hline Former Sovict Union & 32 & 32 & 37 & 31 & 19 & 21 & 17 & 15 & 29 & 27 & 18 & 22 \\
\hline East Asia & 42 & 42 & 62 & 58 & 59 & 57 & 48 & 49 & 54 & 54 & 55 & 49 \\
\hline South Asia & 37 & 32 & 28 & 26 & 30 & 30 & 43 & 35 & 35 & 32 & 43 & 34 \\
\hline Middle East and North Africa & 32 & 33 & 48 & 50 & 50 & 54 & 4] & 49 & 58 & 56 & 47 & 52 \\
\hline
\end{tabular}

Source: Kaufinann, Kraay, and Zoido-Lobatón (2002)

Notes: Each entry in the table indicates percent of countries worldwide that rate below selected country or a region for each governance indicator.

Higher score for any indicator shows better govenance outcome.

All indicators arc subjective or based on individuals' perceptions. Each average is the simple arithmetic average.

1/ OECD denotes the Organization for Econonomic Cooperation and Development.

\section{Summary and Policy Conclusions}

Poverty and inequality are higher in Central America than in Latin America. Latin America, in turn, is the most unequal region of the world in terms of either income or consumption. While poverty declined modestly in the 1990 s, inequality in Central America rose and continues to be high and persistent. This high-and-rising level of inequality is an impediment to pro-poor growth and calls for reforms in several areas studied in this paper, including the composition and level of spending, the quality of education and health, the design and implementation of social safety nets, and reforms in the areas of governance and transparency.

Government education spending has increased only modestly in Central America and remains well below Latin American averages. Studies for developing countries, including all of Central America, stress that increased public spending on education is associated with better indicators of educational attainment, although improvements in initial conditions and governance are also necessary to increase the targeting and efficiency of public spending. Moreover, a reallocation of resources toward basic education can lead to important gains, especially for the poor. Within educational expenditures, teachers' wages are large, especially in Guatemala and Honduras. Teachers' wages in Central America are found to be high by regional standards, and in most Central American countries, teachers earn comparatively more than workers in other professions with similar characteristics and education. However, the evidence linking teacher wages to improved educational achievement is meager at best.

Central America as a region invests relatively large amounts of public resources in health. Studies have found that increased public resources for health care have been associated with the better health status of the population, although the effectiveness of public health care 
spending in promoting health is weaker than that found for public education spending. However, stronger effects have been found in the health status of the poor and in low-income countries, suggesting that better targeting of health care spending would be a powerful tool for poverty reduction. Similarly, improving the efficiency of spending may be as important as increasing the amount of resources.

As the first generation of reforms during the 1990 s are being consolidated in the region, further progress on such reforms requires mainstreaming the complementary secondgeneration reforms. Progress on second-generation reforms invariably involves increasing the transparency of public sector operations, improving governance, solidifying incentives for better performance of the public sector, reforming institutions, and strengthening the rule of law to reduce discretion and opportunities for corruption and poor governance. Recent trends in indicators of governance in Central America are encouraging. There has been progress in voice and accountability and in political stability. However, regulatory quality seems to have deteriorated significantly. Governments should concentrate on improving several aspects of governance and reducing corruption, as these are critical for increasing the effectiveness of public spending and social safety nets, and can lead to improvements in quality and distribution of human capital, promoting higher levels of pro-poor growth. 


\section{REFERENCES}

Alvarez, Benjamin, and J. Majmudar, 2001, "Teachers in Latin America: Who Is Preparing Our Children for the Knowledge Century?" LASHD Paper Series No. 67

(Washington: Latin America, Social and Human Development, World Bank).

Baldacci, Emanuele, Maria Theresa Guin-Siu, and Luiz R. de Mello Jr., 2002, "More on the Effectiveness of Public Spending on Health Care and Education: A Covariance Structure Model," IMF Working Paper No. 02/90 (Washington: International Monetary Fund).

Barro, Robert J., and Jong-Wha Lee, 1996, "International Measures of Schooling Years and Schooling Quality,” American Economic Review, Papers and Proceedings, Vol. 86 (May), pp. 218-23.

- 2000, "International Data on Educational Attainment: Updates and Implications," CID Working Paper No. 42 (Cambridge: Center for International Development, Harvard University).

Barro, Robert J., and Xavier Sala-i-Martin, 1995, Economic Growth (New York: McGrawHill).

Bedi, Arjun Singh, and John H. Y. Edwards, 1997, "The Impact of School Quality on the Level and Distribution of Earnings - Evidence from Honduras," LASHD Paper Series No. 13 (Washington: Latin America, Social and Human Development, World Bank).

Bedi, Arjun Singh, and Jeffery H. Marshall, 1999, "School Attendance and Student Achievement: Evidence from Rural Honduras," Economic Development and Cultural Change, Vol. 47 (April), pp. 657-84.

Behrman, Jere R., and Nancy Birdsall, 1983, “The Quality of Schooling: Quantity Alone Is Misleading," American Economic Review, Vol. 73 (December), pp. 928-46.

Birdsall, Nancy, and Juan Luis Londoño, 1997, "Asset Inequality Matters: An Assessment of the World Bank's Approach to Poverty Reduction," American Economic Review, Papers and Proceedings, Vol. 87 (May), pp. 32-37.

Bourguignon, F., L. Pereira, and N. Stern, 2002, "Evaluating the Poverty Impact of Economic Policies: Some Analytical Challenges," paper presented at the IMF "Conference on Macroeconomic Policies and Poverty Reduction," Washington, March. 
Cardemil, Leonardo, Juan Carlos Di Tata, and Florencia Frantischek, 2000, "Central America: Adjustment and Reforms in the 1990s," Finance \& Development, Vol. 37 (March), pp. 34-37, available via the Internet at http://www.imf.org/external/pubs/ft/fandd/2000/03/cardemil.htm

Case, Anne, and Motohiro Yogo, 1999, "Does School Quality Matter? Returns to Education and the Characteristics of Schools in South Africa," NBER Working Paper No. 7399 (Cambridge, Massachusetts: National Bureau of Economic Research).

Chen, Shaohua, and Martin Ravallion, 2001, "How Did the World's Poorest Fare in the 1990s?" Review of Income and Wealth, Vol. 3 (September), pp. 283-300.

Chu, Ke-young, Hamid Davoodi, and Sanjeev Gupta, 2000, "Income Distribution and Tax and Government Social Spending Policies in Developing Countries," IMF Working Paper 00/62 (Washington: International Monetary Fund).

Corbacho, Ana, 2000, "Labor Markets in Central America: Informal Versus Formal Sectors," Development Discussion Paper No. 747, Central America Project Series (Cambridge, Massachusetts: Harvard University).

—, 2001, Education, Income Distribution, and Growth (Ph.D. dissertation; New York: Columbia University).

—, and Hamid Davoodi, 2002, "Expenditure Issues and Governance in Central America," paper presented at the IMF "Conference on Central America, Potential for Regional Cooperation and Integration," Antigua, Guatemala, July.

Deininger, Klaus, and Lyn Squire, 1996, "A New Data Set Measuring Income Inequality," World Bank Economic Review, Vol. 10 (September), pp. 565-91.

Dollar, David, and Aart Kraay, 2000, "Growth Is Good for the Poor," IMF Seminar Series No. 35 (Washington: International Monetary Fund).

Duryea, Suzanne, and Carmen Pagés, 2002, "Human Capital Policies: What they Can and Cannot Do for Productivity and Poverty Reduction in Latin America," IaDB Research Department Working Paper No. 468 (Washington: Inter-American Development Bank).

Espinosa Ferrando, Jaime, and C. Hernandez Alvarez, 2000, "Productivity and Health Status in Nicaragua," in Wealth from Health: Linking Social Investments to Earnings in Latin America, ed. by William D. Savedoff and T. Paul Schultz (Washington: InterAmerican Development Bank). 
Filmer, Deon, Jeffrey Hammer, and Lant Pritchett, 1998, "Health Policies in Poor Countries: Weak Links in the Chain," Policy Research Working Paper No. 1874 (Washington: World Bank).

Gupta, Sanjeev, Hamid Davoodi, and Erwin Tiongson, 2001, "Corruption and the Provision of Health Care and Education Services," in The Political Economy of Corruption, ed. by Arvind K. Jain, Routledge Contemporary Economic Policy Issues Series (London: Routledge).

Gupta, Sanjeev, Keiko Honjo, and Marijn Verhoeven, 1997, “The Efficiency of Government Expenditure: Experiences from Africa," IMF Working Paper 97/153 (Washington: International Monetary Fund).

Gupta, Sanjeev, and others, 2000, Social Issues in IMF-Supported Programs, IMF Occasional Paper No. 191 (Washington: International Monetary Fund).

__ 2002, "Expenditure Composition, Fiscal Adjustment, and Growth in Low-Income Countries," IMF Working Paper 02/77 (Washington: International Monetary Fund).

Gupta, Sanjeev, Marijn Verhoeven, and Erwin Tiongson, 2001, "Public Spending on Health Care and the Poor," IMF Working Paper 01/127 (Washington: International Monetary Fund).

_ 2002 , "The Effectiveness of Government Spending on Education and Health Care in Developing and Transition Economies," European Journal of Political Economy, Vol. 18, pp. 717-37.

Hanushek, Eric A., John F. Kain, and Steven G. Rivkin, 1998, “Teachers, Schools, and Academic Achievement," NBER Working Paper No. 6691 (Cambridge, Massachusetts: National Bureau of Economic Research).

_ 1999 , "Do Higher Salaries Buy Better Teachers?” NBER Working Paper No. 7082 (Cambridge, Massachusetts: National Bureau of Economic Research).

Hanushek, Eric A., and Dongwook Kim, 1995, "Schooling, Labor Force Quality, and Economic Growth," NBER Working Paper No. 5399 (Cambridge, Massachusetts: National Bureau of Economic Research).

Hanushek, Eric A., and Javier A. Luque, 2002, "Efficiency and Equity in Schools Around the World," NBER Working Paper No. 8949 (Cambridge, Massachusetts: National Bureau of Economic Research).

Harbison, Ralph W., and Eric A. Hanushek, 1992, Educational Performance of the Poor: Lessons from Rural Northeast Brazil (Oxford: Oxford University Press). 
Honduras, 2001, "Poverty Reduction Strategy Paper." Available via the Internet at http:/www.imf.org/External/NP/prsp/2001/hnd/01/index.htm

Inter-American Development Bank, 1996, Como organizar con exito los servicios sociales, Progreso Economico y Social en America Latina, Informe 1996 (Washington).

1998, Facing Up to Inequality in Latin America, Economic and Social Progress in Latin America, 1998-1999 Report (Washington).

- 2000, Social Protection for Equity and Growth. (Washington).

Kaufmann, Daniel, Aart Kraay, and Pablo Zoido-Lobatón, 2002, "Governance Matters II: Updated Indicators for 2000/01," Policy Research Working Paper No. 2772 (Washington: World Bank).

Knowles, Stephen, 2001, "Inequality and Economic Growth: The Empirical Relationship Reconsidered in the Light of Comparable Data," WIDER Discussion Paper No. 128 (Helsinki: United Nations University World Institute for Development Economics Research).

Krueger, Alan B., 2002, "Economic Considerations and Class Size," NBER Working Paper No. 8875 (Cambridge, Massachusetts: National Bureau of Economic Research). , and Diane Whitmore, 2000, "The Effect of Attending a Small Class in the Early Grades on College-Test Taking and Middle School Test Results: Evidence from Project STAR," NBER Working Paper No. 7656 (Cambridge, Massachusetts: National Bureau of Economic Research).

Levin, Henry M., and Mun C. Tsang, 1987, "The Economics of Student Time," Economics of Education Review, Vol. 6, No. 4, pp. 357-64.

Li, Hongyi, Lyn Squire, and Heng-fu Zou, 1998, "Explaining International and Intertemporal Variations in Income Inequality,” Economic Joumal, Vol. 108 (January), pp. 26-43.

Liang, Xiaoyan, 1999, "Teacher Pay in 12 Latin American Countries: How Does Teacher Pay Compare to Other Professions? What Determines Teacher Pay? Who Are the Teachers?" LASHD Working Paper No. 49 (Washington: Latin America, Social and Human Development, World Bank).

Martinic, Sergio, 1998, "Tiempo y Aprendizaje," LASHD Paper No. 26 (Washington: World Bank, Department of Human Development, Latin America, Social and Human Development).

Nicaragua, 2001, "A Strengthened Growth and Poverty Reduction Strategy." Available via the Internet at http://www.imf.org/External/NP/prsp/2001/nic/01/index.htm 
Ravallion, Martin, 1997, "Can High-Inequality Developing Countries Escape Absolute Poverty?” Economics Letters, Vol. 56 (September), pp. 51-57.

_ 2001, "Growth, Inequality and Poverty: Looking Beyond Averages," World Development, Vol. 29 (November), pp. 1803-15.

— , and Shaohua Chen, 1997, "What Can New Survey Data Tell Us About Recent Changes in Distribution and Poverty?" World Bank Economic Review, Vol. 11 (May), pp. 357-82.

Ravallion, Martin, and Gurave Datt, 2001, "Why Has Economic Growth Been More ProPoor in Some States of India than in Others?" Journal of Development Economics.

Savedoff, William D., and Paul Schultz, eds., 2000, Wealth from Health: Linking Social Investments to Earnings in Latin America (Washington: Inter-American Development Bank).

Székely, Miguel, 2001, "The 1990s in Latin America: Another Decade of Persistent Inequality, But With Somewhat Lower Poverty," IaDB Research Department Working Paper No. 454 (Washington: Inter-American Development Bank).

Wang, Limin, 2001, "Health Outcomes in Low-Income Countries and Policy Implications: Empirical Findings from Demographic and Health Surveys" (unpublished; Washington: World Bank).

Wodon, Quentin T., ed., 2000, "Poverty and Policy in Latin America and the Caribbean," World Bank Technical Paper No. 467 (Washington).

World Bank, 2002, World Development Indicators 2002 (Washington).

Young, Phillip, and others, 2001, The Dominican Republic: Stabilization, Reform, and Growth, IMF Occasional Paper No. 206 (Washington: International Monetary Fund). 